\title{
Translation of RNA Coliphages by Amino Acid-incorporation Systems of the Enterobacteriaceae
}

\author{
By R. HOWK, S. S. SARIMO AND M. J. PINE \\ Department of Experimental Therapeutics, Roswell Park Memorial Institute, \\ 666 Elm Street, Buffalo, New York, 14203, U.S.A.
}

(Received I 8 July 1972)

\begin{abstract}
SUMMARY
Crude cell-free amino acid-incorporating systems derived from a variety of enterobacterial species are not uniform in their ability to translate RNA of the coliphages $\mathrm{Q} \beta$ or MS 2. Escherichia coli, Shigella alkalescens and to a lesser extent Citrobacter freundii translate effectively under standard conditions, but Salmonella typhimurium, S. pomona and Proteus morganii do not. Ineffective species do not generally inactivate phage RNA faster than effective ones, and they are as effective as $E$. coli in their general capacity for mRNA translation. This was judged in representative species by the incorporation of phenylalanine and leucine labels as directed by polyuridylate or mRNA of phage-infected $S$. typhimurium, and from the relative incorporation of methionine label into the normal initiating $N$-formylmethionine residues of polypeptides. The ribosomal rather than the soluble components appear responsible for ineffectiveness in translation.
\end{abstract}

\section{INTRODUCTION}

Microbial amino acid-incorporating systems are sometimes selective in their translation of the RNAs of Escherichia coli RNA phages. Incompatibilities may be conferred by specific modifying factors (Hsu \& Weiss, 1969; Dube \& Rudland, I970; Morrison \& Malamy, I97I), or they may also normally exist in polypeptide incorporating systems of Bacillus stearothermophilus (Lodish, 1970) and a psychrophilic pseudomonad (Szer \& Brenowitz, 1970). We have also observed that Streptococcus faecium preparations are unable to translate RNA of the $\mathrm{Q} \beta$ phage of $E$. coli at high or low $\mathrm{Mg}^{+2}$ levels (Sarimo \& Pine, I97I ; and unpublished experiments). In reconstitution experiments with $E$. coli components, the soluble streptococcal components were competent in translating this RNA but the ribosomes were not. The latter also could not bind $\mathrm{Q} \beta$ RNA with $\left[{ }^{35}\right.$ S]formylmethionyl-tRNA in initiation complexes (Sarimo \& Pine, I97I). We now report incompatibilities in translation of $E$. coli RNA phages by even more closely related species of the Enterobacteriaceae.

\section{METHODS}

The procedure of Nirenberg (1963) was used with minor modification for the growth of bacteria, preparation of incubated, dialysed $\mathrm{S}_{3} 0$ extracts and assay of amino acid incorporation. $\left.{ }^{35} \mathrm{~S}\right] \mathrm{Methionine}$ and a mixture of ${ }^{35} \mathrm{~S}$-labelled methionyl and $\mathrm{N}$-formylmethionyltRNAs were prepared from Escherichia coli (Sarimo \& Pine, 1971). Labelled $N$-formylmethionyl and internal methionyl residues in the proteins were determined from their electrophoretic peaks after pronase digestion (Pine, Gordon \& Sarimo, I969). Preparation of MS 2 phage RNA was modified from a previous procedure (Davis \& Sinsheimer, I963). $N$-Acetylphenylalanine-containing tRNA was prepared by the method of Haenni \& Chape- 
Table I. Efficiency of $S_{3} 0$ extracts of Enterobacteria in translating $Q \beta R N A$ and poly $U$

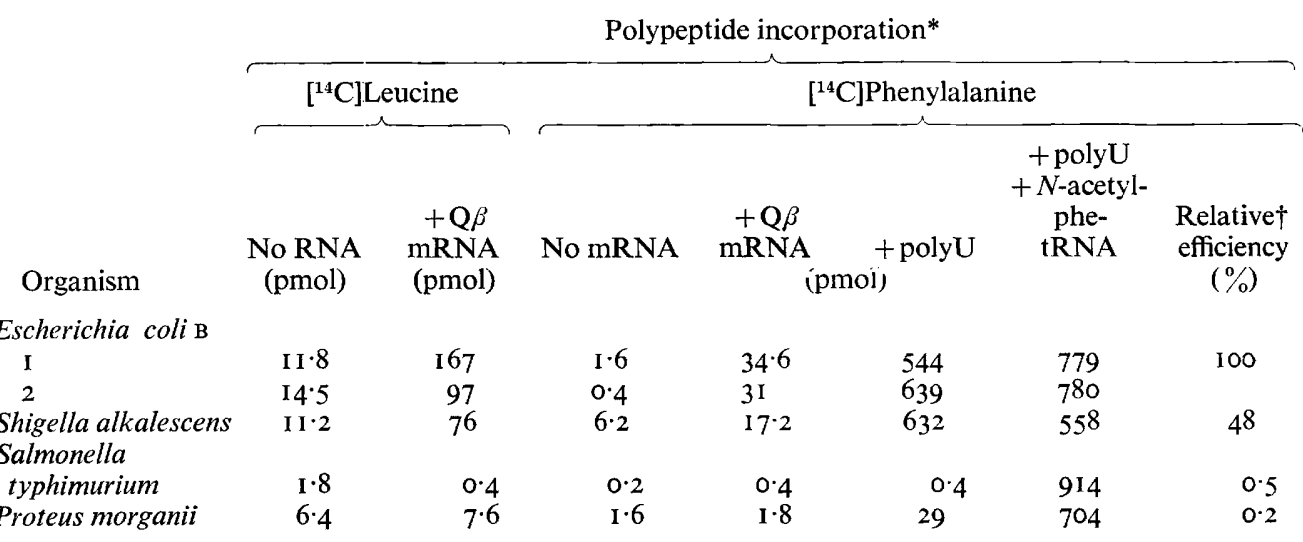

* Reaction mixtures contained per $0.25 \mathrm{ml}$ : 10 mM-tris (hydroxymethyl) amino methane $\mathrm{HCl}, \mathrm{pH}_{7} \cdot 8$; $60 \mathrm{mM}-\mathrm{KCl} ;$ Io $\mathrm{mM}-\mathrm{NH}_{4} \mathrm{Cl} ; 8 \mathrm{~mm}-\beta$-mercaptoethanol; $5 \mathrm{mM}-\mathrm{Mg}$ acetate; preneutralized $6 \mathrm{~mm}-\mathrm{Na}$ phosphoenol pyruvate; $4 \mathrm{mM}-\mathrm{ATP} ; 0.4 \mathrm{mM}-\mathrm{GTP}$; $\mathrm{I} \mu \mathrm{g}$ leucovorin; $\mathrm{x} \mu \mathrm{g}$ labelled amino acid containing $\mathrm{I} \cdot 5 \times \mathrm{IO}^{5}$ c.p.m.; $5 \mu \mathrm{g}$ of all other amino acids, 9.4 to I8.7 $E_{260 \mathrm{~nm}}$ of S 30 extract; and $107 \mu \mathrm{g}$ polyU with $N$-acetyl phe-tRNA at $6.3 E_{260 \mathrm{~m}}$ units or $50 \mu \mathrm{g} \mathrm{Q} \beta$ phage RNA. Components were incubated at $37^{\circ} \mathrm{C}$ for $30 \mathrm{~min}$.

$\dagger \mathrm{I} 00 \times(\mathrm{Q} \beta$ RNA-directed enterobacterial incorporation $/ \mathrm{Q} \beta$ RNA-directed $E$. coli incorporation): (polyU $+N$-acetylphe-tRNA-directed enterobacterial incorporation/polyU $+N$-acetylphe-tRNA-directed E. coli incorporation).

ville (1966). Crude RNA enriched with phage P 22 mRNA was prepared from lysogenic Salmonella typhimurium treated for $60 \mathrm{~min}$ with $8 \mu \mathrm{g} / \mathrm{ml}$ of mitomycin C and extracted with phenol (Bolle, Epstein \& Salzer, 1968). Purified Q $\beta$ phage RNA was obtained from Dr B. A. Bassel, State University of New York Upstate Medical Center.

\section{RESULTS AND DISCUSSION}

Initially, translation of $\mathrm{Q} \beta$ RNA was examined in four enterobacterial species with uniformly labelled $\left[{ }^{14} \mathrm{C}\right]$ leucine and phenylalanine (Table I). Only Escherichia coli and the closely related Shigella alkalescens translate $\mathrm{Q} \beta$ RNA effectively, but Salmonella typhimurium and Proteus morganii do not. The same relative results were also obtained at incorporation times of 10 to $60 \mathrm{~min}$ and at the higher $\mathrm{Mg}^{+2}$ concentrations of $\mathrm{I} 0$ to $\mathrm{I} 4 \mathrm{mM}$. Incorporation was generally linear with time or began after a slight lag, and was maximal at $30 \mathrm{~min}$. All species translate polyU, however, and, at the low $\mathrm{Mg}^{+2}$ concentrations used, they are variably dependent on $\mathrm{N}$-acetylphenylalanyl-tRNA as an initiator (Table I). In other experiments they also incorporated similar amounts of labelled $\left[{ }^{35} \mathrm{~S}\right]$ methionine into normal initiator $N$-formylmethionyl-tRNA.

To determine whether the destruction of mRNA was responsible for poor translation activity, phage $\mathrm{Q} \beta$ RNA was added to one-fifth the normal amount of $\mathrm{S}_{3} 0$ extract under the standard conditions of polypeptide incorporation. The labelled leucine was added $30 \mathrm{~min}$ afterwards together with a normal amount of $\mathrm{Q} \beta$-translating Escherichia coli extract that minimized the contribution of the first extract. $\left[{ }^{14} \mathrm{C}\right]$ Leucine incorporation was reduced to varying extents by each pre-incubation, but the extent of reduction did not correlate with competence of the extracts in translating $\mathrm{Q} \beta$ RNA. Thus the incompatibilities in translation do not appear to be determined by mRNA destruction.

Enterobacterial translation was further investigated with RNA of the coliphage MS2 
Table 2. Polypeptide incorporations directed by RNAs of $M S 2$ phage, Escherichia coli ribosomes and phage P22-infected Salmonella cells

\begin{tabular}{|c|c|c|c|c|}
\hline & \multicolumn{3}{|c|}{$\begin{array}{c}{\left[{ }^{14} \mathrm{C}\right] \text { Phenylalanine incorporation } *} \\
\text { net } \mathrm{pmol} / 30 \mathrm{~min} / \text { tube }\end{array}$} & \multirow{2}{*}{$\begin{array}{l}{\left[{ }^{35} \text { S]Methionine }\right.} \\
\text { incorporation } \dagger \\
N \text {-formylmethi- } \\
\text { onine: methionine } \\
\text { P 22-Salmonella }\end{array}$} \\
\hline tract & $\begin{array}{l}\text { PolyU }+N- \\
\text { acetylphenyl- } \\
\text { alanine-tRNA }\end{array}$ & $\begin{array}{l}\text { MS } 2 \\
\text { RNA }\end{array}$ & $\begin{array}{l}\text { P 22-Salmonella } \\
\text { RNA }\end{array}$ & \\
\hline er freundii & 697 & 13 & 一 & - \\
\hline hia coli & 276 & 142 & 56 & I $: 5 \cdot 4$ \\
\hline la pomona & I I I & 2 & 34 & I $: 5 \cdot 3$ \\
\hline $\begin{array}{l}\text { hia coli: Salmonella } \\
\text { Ia } \mathbf{I}: \mathrm{I}\end{array}$ & 204 & $25 \cdot 2$ & $20 \cdot 2$ & - \\
\hline $\begin{array}{l}\text { hia coli ribosomes }(2 \times) \\
\text { monella pomona supernate }\end{array}$ & 724 & 82 & 29 & $\longrightarrow$ \\
\hline $\begin{array}{l}\text { lla pomona ribosomes }(2 \times) \\
\text { herichia coli } \text { supernate }\end{array}$ & 178 & 0.9 & $7 \cdot 2$ & - \\
\hline
\end{tabular}

\section{Citrobacter freundi}

Escherichia coli

Salmonella pomona

Escherichia coli: Salmonella

pomona I: I

Escherichia coli ribosomes $(2 \times)$

+ Salmonella pomona supernate

Salmonella pomona ribosomes $(2 \times)$

+ Escherichia coli supernate

* Components and conditions as in Table I, with the following modifications per $0.25 \mathrm{ml}$ volume: $5.6 \mathrm{~mm}$ $\mathrm{Mg}$ acetate; $5 \mathrm{~mm}$-spermidine $3 \mathrm{HCl}$; $10 \mathrm{~mm}$-putrescine $2 \mathrm{HCl}$; plus mRNAs as follows: $1242 \mu \mathrm{g} \mathrm{RNA}$ extracted from purified Escherichia coli ribosomes; $80 \mu \mathrm{g}$ polyU with I20 $\mu \mathrm{g} N$-acetylphe-tRNA (unfractionated); $200 \mu \mathrm{g}$ phage MS 2 RNA or $736 \mu \mathrm{g}$ RNA of phage P 22-infected Salmonella typhimurium. Ribosomes in reconstituted mixtures were at twice the $\mathrm{S} 30$ level.

+ Components and conditions as above, but proportionately in $\mathbf{I ~} \mathrm{ml}$ volume and with label as $\left.{ }^{35} \mathrm{~S}\right]-$ methionine, approximately $\mathrm{I} \mathrm{mc} / \mathrm{mmol}, \mathrm{I} \cdot 5 \times 10^{6} \mathrm{c} . \mathrm{p} . \mathrm{m}$. added as the free amino acid and 109000 c.p.m. charged to I.8 mg Escherichia coli в tRNA. Individual electrophoretic peaks of $N$-formylmethionine and methionine ranged from 308 to 2689 c.p.m. Backgrounds without mRNA were negligible.

(Table 2). In these assays, spermidine and putrescine, which slightly stimulated translation generally, were added with an optimal amount of $\mathrm{Mg}^{+2}$. Escherichia coli is effective, Citrobacter freundii marginally effective and Salmonella pomona ineffective in translating MS 2 RNA, as judged by phenylalanine incorporation. In contrast, all are effective in translating polyU. Salmonella pomona and E. coli are also about equally effective in translating mRNA prepared from phage $\mathbf{P} 22$-infected S. typhimurium. With $\left[{ }^{35} \mathrm{~S}\right]$ methionine as the label, approximately one of six to seven residues incorporated into polypeptides is $N$-formylated in both $E$. coli and $S$. pomona preparations (Table 2). The normal removal of the initiating formyl residues is inhibited under these conditions (Adams, I968). Judging from the $N$-formylmethionine content of the synthesized polypeptides, translation of the crude mRNA must frequently begin at the initiating AUG codon. The incompatibility of $S$. pomona in translating RNA of the MS 2 phage therefore cannot be due to a lowered general capacity for initiating translation of normal mRNAs. Ribosomal RNA has no mRNA activity in any of the preparations. Treating the host system used for preparing P 22 mRNA with $30 \mu \mathrm{g} / \mathrm{ml}$ of rifampicin for 20 min also markedly reduces mRNA activity. These characteristics further attest that authentic mRNAs are being translated. When the ribosomes and supernatant factors of $E$. coli and $S$. pomona are interchanged, the incompatibility of $S$. pomona in MS 2 RNA translation appears due to the ribosomal and not the soluble component (Table 2). In an additional experiment crude initiation factors prepared from $E$. coli ribosomes did not clearly improve MS 2 RNA translation by $\mathrm{S}_{30}$ extracts or ribosomal components of $S$. pomona.

In conclusion, effectiveness in translating the RNAs of RNA-containing coliphages appears to vary among enterobacterial preparations that otherwise effectively translate polyU or a mixture of mRNAs of combined bacterial and DNA phage origin, and have similar 
ability to initiate translation normally with $N$-formylmethionine residues. Escherichia coli and Shigella alkalescens tribally allied in the Eschericheae, and to a limited extent Citrobacter freundii (Salmonelleae) can translate the RNA phages of E. coli, while other representatives outside of the Eschericheae (Salmonella typhimurium, S. pomona and Proteus morganii) did not effectively do so. Comparisons have been based on translation of very different mRNAs under standard conditions and hence are not absolute. The ribosomes, which are likely responsible for the poor compatibilities, could be modified by phages or episomes (Hsu \& Weiss, 1969; Dube \& Rudland, 1970; Morrison \& Malamy, 1971), but as the incidence of poor compatibility is high the differences are more likely inherent. Since the genome of RNA-containing coliphage can sometimes be effectively translated by phylogenetically remote systems (Schwartz, Eisenstadt, Brawerman \& Zinder, I965), translational variations may in part reflect random differences among ribosomes.

The incompatibility of one of the species tested here, Salmonella typhimurium in translating $\mathrm{Q} \beta$ RNA has recently been confirmed in another laboratory (B. A. Bassel, private communication). In preliminary studies deficiencies appeared in ribosomal attachment of the RNA and the extent of translation.

This research was supported in part by grants CA-07777 and CA-I 3038 of the National Cancer Institute.

\section{REFERENCES}

ADAMS, J. M. (I968). On the release of the formyl group from nascent protein. Journal of Molecular Biology 33, 57I-569.

Bolle, A., Epstein, R. H. \& Salzer, W. (1968). Transcription during bacteriophage T4 development: Synthesis and relative stability of early and late RNA. Journal of Molecular Biology 3r, 325-348.

DAVIS, J. E. \& Sinsheimer, R. L. (I963). The replication of bacteriophage MS 2. I. Transfer of parental nucleic acid to progeny phage. Journal of Molecular Biology 6, 203-207.

Dube, S. K. \& Rudland, P. S. (I970). Control of translation by T4 phage: altered binding of disfavoured messengers. Nature, London 231, 820-823.

HaEnNi, A. L. \& Chapeville, F. (1966). The behaviour of acetylphenylalanyl soluble ribonucleic acid in polyphenylalanine synthesis. Biochimica et biophysica acta 114, I35-148.

Hsu, W. T. \& WEISs, S. B. (Ig69). Selective translation of T4 template RNA by ribosomes from T4-infected Escherichia coli. Proceedings of the National Academy of Sciences of the United States of America 64, 345-35I.

LoDISH, H. F. (I970). Specificity in bacterial protein synthesis: role of initiation factors and ribosomal subunits. Nature, London 226, 705-707.

Morrison, T. G. \& Malamy, M. H. (I97I). T7 translational control mechanisms and their inhibition by $F$ factors. Nature New Biology 23r, 37-4I.

NirenberG, M. W. (I963). Cell-free protein synthesis directed by messenger RNA. Methods in Enzymology 6, $17-27$.

Pine, M. J., Gordon, B. \& S.ARImo, S. S. (1969). Protein initiation without folate in Streptococcus faecium. Biochimica et biophysica acta $\mathbf{1 7 9}, 439-447$.

SARIMO, S. S. \& PINE, M. J. (197I). Evidence for the requirement of methionyl tRNA modification for in vitro polypeptide initiation in Streptococcus faecium. Biochimica et biophysica acta 240, 233-236.

Schwartz, J. H., Eisenstadt, J. M., Brawerman, G. \& Zinder, N. D. (1965). Biosynthesis of the coat protein of coliphage $\mathrm{f}_{2}$ by extracts of Euglena gracilis. Proceedings of the National Academy of Sciences of the United States of America 53, 195-200.

Szer, W. \& Brenowitz, J. (I 970). Translation of MS 2 RNA by ribosomes from different bacterial species. Biochemical and Biophysical Research Communications 38, I $154-1160$. 